\title{
Determinant Factors Affect the Implementation of Laboratory Work in Science Subjects at Secondary Schools in Bale Zone, Ethiopia
}

\author{
Abebe Adugna Chala* Ibrahim Kedir Shiferaw Wami, \\ Esayes Aklilu(Assistant Prof.) Tekalign Kassa(Assistant Prof.) \\ College of Natural and Computational Science in Madda Walabu University, P. O Box 247, Bale Robe Ethiopia'
}

\begin{abstract}
The research is financed by Madda Walabu University, Bale Robe, Ethiopia
Abstract

Laboratory work as a teaching and learning science is prominence in the Ethiopian curriculum for secondary school. It is emphasized that students should be given opportunities to develop the ability to search for answers to questions, plan, and conduct, interpret and present results. Moreover, students should also be encouraged to use their science knowledge to communicate, argument and present conclusions. But incorporating laboratory work curriculum and implementing in real context are different things. Because of different factors it is not implemented in most cases in Ethiopian. Hence, the objective of this research was to determine factors that affect the implementation of laboratory work in science subjects at Secondary Schools in Bale Zone. There are about 57 secondary schools found in Bale zone and from these 6 schools from pastoralist and 5 schools from pastoralist a total sample size of 11 schools using stratified sampling method. Primary data was gathered from teachers, school principals and students. Secondary data were collected from natural science books (physics, chemistry and biology), documents such as annual plans, laboratory reports, annual reports and exam papers. The find of research has showed that the major hindering factors for laboratory works to be functional are shortage lab technician and resources (lab materials, chemicals, well organized and separated Laboratory room) and large class size. The educational offices should seriously plan and enforce the provision of the required facilities for the schools and professional support for the teachers. The school environment should be facilitated to handle the implementation of the Laboratory works.
\end{abstract}

Keywords: Determinant factors, Laboratory work, science subjects, Secondary Schools.

DOI: $10.7176 / \mathrm{JEP} / 10-13-09$

Publication date:May $31^{\text {st }} 2019$

\section{Introduction}

The terms laboratory work, practical work and experiment are often used synonymously. Hult (2000) defines experiment as an activity where students are offered opportunities to try and verify a thought or a theory. The term laboratory work can be equalized with the term experiment but can also be used to illustrate something that can be a theory as well as a procedure Hult (2000). The definition of practical work becomes an expansion of the terms experiment and laboratory work, where the student is not just a passive auditor or observer. The experiment is a subset of the laboratory work that is a subset of the practical work, which can be considered as one of many different teaching and learning methods Hodson (1988). Practical work does not necessarily imply that students are doing laboratory work, but it could mean students are engaged in activities such as making a collage, building a model or role-playing. All activities and learning methods where the students are active as practical work Hodson (1988).

All this different possible aims show the potential and versatility of using laboratory work as learning and teaching method in science education. Several of the above-mentioned aims could be automatically addressed just by routinely performing laboratory work. However, this is not sufficient as the real effects of students' learning are shown to be scarce. The practical work was generally effective in getting students to do what was intended but significantly less effective in getting students to use the intended scientific ideas to guide their actions and reflect Abrahams and Millar (2008). The cognitive challenge, in terms of linking observables to ideas failed to appear. The successful pedagogy depends crucially on teachers being clear about the purpose of each learning experience and refining their approach to improve students' learning outcomes Hodson (2014). The students are well aware of a specific laboratory works' aim, as such information usually is given as the opening line of the teacher's introduction Hart, Mulhall, Berry, Loughran and Gunstone (2000). The students' learning outcomes from the laboratory work could be improved, if teachers explained the intended objectives of laboratory work besides telling them what to do Jacobsen (2010).

Secondary school is the base in preparing students for science education. It is at this level they were exposed to laboratory equipment, activities and precaution or safety rules. A high school laboratory should have the equipment necessary to conduct meaningful demonstrations and experiments. However, Practical work is not done in many countries do not implement due to inadequate resources, lack of practical science skills and large classes 
in science Onwu \& Stoffel, 2005; Ramnarain, (2014). In South African schools teachers do not use practical work to teach physical sciences Hatting \& Rogan, 2007). The main factors for the failure of implementation include: some teachers teaching subjects in which they are not specialized (Mokotedi, 2013); lack of laboratories and equipment; lack of laboratory technicians; and large classes. Non-specialist teachers are known to be reluctant to do practical work (SCORE, 2008; Soares\& Lock, 2007; Abrahams \& Millar, 2008). Several studies also point to learners' persistent lack of experimentation skills (Onwu\&Stoffels (2005); Ramanrain (2014).

Research conducted in Ethiopia indicates that secondary students do not receive the practical experiences specified in the official science curriculum Samuel Bekalo \&Geoff Welford, 2010. About 85.97\% of laboratory activities were not done in science education at secondary schools of Ilu Aba Bora zone (Feyera 2014). In the same way, about $75 \%$ students had not been engage with practical activities while learning Physics (Endalamaw and et al., 2017). In well-organized way practical works may not be implemented in real context because of the sophisticated factors identified by different researchers which are related to school facilities, teachers' competency and motivations, teachers' work load and large class size. These barriers of the context of implementation should be properly identified and tackled.

The purpose of laboratory work in science education are motivation for students, the excitement of discovery, consolidation of theory, development of manipulative skills, knowledge of standard techniques, general understanding of data handling, development of other skills (e.g. analytic, evaluative, planning, applied, mathematical) and understanding of how science works: concepts of scientific process, collaborative working, reproducible results, fair testing (Watts 2013, p.4). Learners do laboratory work to expand their knowledge in an attempt to understand the world around them (Kolucki\&Lemish, 2011). For these purposes laboratory work specified in the secondary school science curriculum should be given due attention. Otherwise teaching the students to memorize facts and formulas only encourage memorization which is contrary to the goals of science education in general and science education in particular.

Generally, incorporating Laboratory work the curriculum and implementing in real context are different things. Smartly intended laboratory work may not be implemented in real context because of the different sophisticated factors identified by different researchers which are related to school facilities, teachers' competency and motivations, teachers' work load and large class size. Hence, there is no research that conducted in this area to investigate factors affect the implementation of laboratory work in science subjects at secondary schools.

The objective of this study was to identify factors affecting the implementation of the science laboratory work in the secondary schools of Bale zone. The research will be carried out in 11 secondary schools of Bale zone. In these schools only grade 10 students, Science teachers, principals will be considered as the subjects of the study. The main reason to consider grade 10 is relevant and valuable data can be obtained because they have more experience and good communication skill.

\section{Methodology}

\subsection{Description of the Study area}

The study was conducted in Bale Zone which is located in south east Ethiopia. In this zone both about eight district pastoralist (low land and remote areas) and nine districts are found agro pastoralist (high land and likely urban areas). According to the Bale Zone Education office, there are 57 secondary schools and number of grade 10 students in the year 2017/2018 an estimated enrolment of 9,425 5 Grade 10 students.

\subsection{Research Design}

To extensively investigate the level of implementation of laboratory work and effectively analyze the effect of the training of Madda Walabu University on the implementation of laboratory work and institutional based Survey was used as research design.

\subsubsection{Sampling frame, Sample size and sampling techniques}

The target population was grade 10 students, science teachers, school principals of the sample schools. The number of Secondary Schools of Bale Zone (49) were divided in the two clusters namely pastoralist (relatively remote areas from zonal town and high land area) and agro pastoralist (relatively close to zonal town and high land areas). The number of sampled schools were selected from each clusters based on (Geneserth et al, 1987), which is the sample size of $10 \%$ to $20 \%$ is acceptable in a descriptive survey study. Thus, taking $20 \%$ of sampled schools from each cluster, 6 schools from pastoralist and 5 schools from pastoralist a total of 11 schools were selected using simple random sampling method. Secondary schools were taken from pastoralist: Sofumer, Welabu, MelkaMicha, Delomena, HaroDumel, Agetu; and Secondary Schools were taken from agro pastoralists' areas. Galame, Agarfa, Gasera, Goba, Goro and Ginir

In a descriptive survey study the sample size is acceptable when $10 \%$ to $20 \%$ the total secondary schools in Bale zone which has been recommended (Geneserth et al,1987). Simple random sampling technique was used to select 404 students, 33 from each school All the science teachers and principals in the selected schools were taken purposively since their numbers are manageable in each school. To select sample size of grade 10 students from 
these schools Yamane (1967) provides a simplified formula with a 95\% confidence level and 5\% precision level (e). $n=\frac{N}{1+N\left(e^{2}\right)} \quad$ Where $\mathrm{n}=$ Sample size, $\mathrm{N}=$ Total population, $\mathrm{e}=$ precision level $=0.05$. There were about 9,425 students in total secondary schools of Bale zone were enrolled to learn in the year 2017 G.C. Hence based on the formula stated 384 students and 5\% that is 20 and a total of 404 students were used in this study.

\subsubsection{Procedure of Data Collection}

The sample size for each school was set using the target student population of each school. Subsequently, discussions were conducted with principals of each school as to how to distribute the questionnaires for students. Before the students started to fill in the questionnaire, the purpose of the study was explained by the researchers and oral instructions were also given. Observation checklists were prepared and filled for each school and in depth interview for principals was conducted as per the schedule for each school. Secondary data were collected from natural science books (physics, chemistry and biology), documents such as annual plans, laboratory reports, annual reports and exam papers.

\subsubsection{Pilot Testing}

For close-ended questionnaire prepared for students, Pilot testing was conducted on a total of 50 students at Robe secondary school of grade 10 . Adjustments were made on vague questions which were raised by the students. The numbers of male and female participants were taken proportional. Finally, the responses of the participants were used and entered to SPSS version 20 to compute item inter correlation and Cronbach-Alpha in order to evaluate the scales and their reliability.

\section{Data Analysis and Interpretation}

This part of the study deals with presentation, analysis and interpretation of data gathered from students, Natural science teachers, school principals and observation checklists using instruments mentioned in the preceding chapter.

A total of 404 questionnaires were distributed for students, and 380 were returned. Among these 345 questionnaires were properly filled. From the proposed of 92 Natural science teachers 72 were available the schools and questionnaires were distributed for them as a result all were correctly filled and returned. The schools principals in all the sample schools were also interviewed.

Table 3.1 Characteristics of the respondents

\begin{tabular}{|c|c|c|c|c|c|}
\hline S.No & Respondents & \multicolumn{2}{|l|}{ Characteristics } & $\mathrm{N}$ & $\%$ \\
\hline \multirow[t]{8}{*}{1} & \multirow[t]{8}{*}{ Natural Science teachers } & \multirow[t]{2}{*}{ Sex } & $\mathrm{M}$ & 58 & $81 \%$ \\
\hline & & & $\mathrm{F}$ & 14 & $19 \%$ \\
\hline & & \multirow[t]{3}{*}{ Qualification } & Diploma & - & \\
\hline & & & Digree & 72 & $100 \%$ \\
\hline & & & Above BSc/Bed & - & \\
\hline & & \multirow[t]{3}{*}{ Year of experience } & $0-5$ years & 34 & $47 \%$ \\
\hline & & & $5-10$ years & 25 & $35 \%$ \\
\hline & & & Above 10 years & 13 & $18 \%$ \\
\hline \multirow[t]{5}{*}{2} & \multirow[t]{5}{*}{ School principals } & \multirow[t]{3}{*}{ Qualification } & Diploma & & \\
\hline & & & Degree & 7 & $58 \%$ \\
\hline & & & Above BSc/Bed & 5 & $42 \%$ \\
\hline & & \multirow[t]{2}{*}{ Year of experience } & $0-5$ years & 3 & $25 \%$ \\
\hline & & & $5-10$ years & 5 & $42 \%$ \\
\hline 3 & & & Above 10years & 4 & $33 \%$ \\
\hline \multirow[t]{2}{*}{4} & \multirow[t]{2}{*}{ Students } & \multirow[t]{2}{*}{ Sex } & $\mathrm{M}$ & 215 & $53 \%$ \\
\hline & & & $\mathrm{F}$ & 189 & $47 \%$ \\
\hline
\end{tabular}

\subsection{Data Analysis}

Questionnaires were administered to trained natural science teachers to analyze the effect of the training provided by Madda Walabu University on Laboratory work (2013-2015). The questionnaires were designed to measure the effect of the training in their work experience, and the change observed in school practices on laboratory work $\mathrm{s}$ as a result of the training. The closed ended parts of the questionnaire were tabulated as follows while the openended responses were qualitatively analyzed where important. 
Table3.2: The status of implementation of science laboratory work $\mathrm{s}$ in the schools which receive the training and those which did not receive the training [None of the practical activities implemented (X), Less than 50\% of the practical activities are implemented (囚), More than $50 \%$ of the practical activities are implemented $(\sqrt{ })]$

\begin{tabular}{|c|c|c|c|c|c|c|}
\hline & \multirow[t]{2}{*}{ S.No } & \multirow[t]{2}{*}{$\begin{array}{l}\text { Name of the } \\
\text { school }\end{array}$} & \multicolumn{3}{|c|}{$\begin{array}{l}\text { Laboratory work implementation } \\
\text { status for each subject }\end{array}$} & \multirow[t]{2}{*}{ Remark } \\
\hline & & & Biology & Chemistry & Physics & \\
\hline \multirow{6}{*}{ 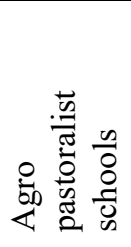 } & 1 & Agarfa & $\mathrm{X}$ & $\mathrm{X}$ & $\mathrm{X}$ & \\
\hline & 2 & Goro & $\mathrm{X}$ & $X$ & $\mathrm{X}$ & \\
\hline & 3 & Ginnir & $\sqrt{ }$ & $\sqrt{ }$ & $\sqrt{ }$ & \\
\hline & 4 & Gasara & $\mathrm{X}$ & $\mathrm{X}$ & $\mathrm{X}$ & \\
\hline & 5 & Galama & $X$ & $\mathrm{X}$ & $\mathrm{X}$ & \\
\hline & 6 & Negadde & $\mathrm{X}$ & $\mathrm{X}$ & $\mathrm{X}$ & \\
\hline \multirow{5}{*}{ 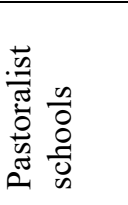 } & 7 & Walabu & $\mathrm{X}$ & $\mathrm{X}$ & $\mathrm{X}$ & \\
\hline & 8 & Dallo Manna & 区 & $\mathbf{x}$ & $\mathbf{x}$ & \\
\hline & 9 & Angentu & $\mathrm{X}$ & $\mathrm{X}$ & $\mathrm{X}$ & \\
\hline & 10 & Sofumer & $\mathrm{X}$ & $\mathrm{X}$ & $\mathrm{X}$ & \\
\hline & 11 & Melka Micca & $\mathrm{X}$ & $\mathrm{X}$ & $\mathrm{X}$ & \\
\hline
\end{tabular}

As it can be seen from table 3.2 above, there is no difference in implementation status of laboratory work in schools those from pastoralist and agro pastoralist. The practical activities were better exercised in Ginnir only and partially practiced in Negade secondary schools of which it is about $18 \%$ of the total sample schools. The reason was in Ginir secondary schools there is separate laboratory room and availability of lab techinitians to manage and assist science teachers. But in caase of Negade secondary schools interview with the corresponding principals shows that the changes were because of the efforts of the schools (material and professional supports from NGO).

Some research finding indicates that reason for very little implementing practical activities were lack of concern and support of school principals (Endalamaw and et al., 2017). Adequate planning by the school head, with appropriate involvement of teachers, learners, parents and the community, can raise curriculum standards and help the school meet learning achievement goals and successfully implement their important policy directives or targets.

Laboratory work specified in natural sciences curricula requires conditions conducive for their implementation. As the findings in section 3.1 and 3.2 indicated, laboratory work specified in natural sciences curricula almost are not being implemented in 9 schools of which it is about $82 \%$ of the total sample schools. The result also indicated that the training provided by Madda Walabu University on laboratory work also could not bring any change. This is also confirmed by an interview question for principals of the schools. A question "Are the practical activities specified in science curriculum being implemented in your secondary school?" was administered to the principals of the secondary schools. The response indicated that in almost all the secondary schools the practical activities were not being implemented.

The principals were also asked to mention the major factors affecting the implementation of the practical activities. Lack of motivation from the teachers, Large class size and great work load, Lack of practical skills and professional support, Lack of lab technician (except Agarfa and Ginnir secondary schools), Lack of lab manual, Lack of Lab materials (in most schools) These factors are also identified by different researches as the ones affecting the performance of laboratory work (SCORE, 2008; Soares\& Lock, 2007; Abrahams \& Millar, 2008). The results of the observation checklists also support these findings. Table 3.6 is the summery of the observation checklists recorded for each school. 
Table 3.3 Observation checklist for school facilities for Grade 9 [Available $(\sqrt{ })$, Not available(x), available and separate for each subject $(*)]$

\begin{tabular}{|c|c|c|c|c|c|c|c|c|c|}
\hline \multirow{2}{*}{$\begin{array}{c}\mathrm{S} \\
\text { No }\end{array}$} & \multirow{2}{*}{$\begin{array}{l}\text { School } \\
\text { Name }\end{array}$} & \multicolumn{7}{|c|}{ School facilities } & \multirow[b]{2}{*}{ Remark } \\
\hline & & $\begin{array}{c}\text { Lab } \\
\text { room }\end{array}$ & $\begin{array}{c}\text { Lab } \\
\text { manual }\end{array}$ & $\begin{array}{c}\text { Lab } \\
\text { technician }\end{array}$ & $\begin{array}{c}\text { Lab } \\
\text { materials }\end{array}$ & $\begin{array}{l}\text { Schedule } \\
\text { for lab }\end{array}$ & $\begin{array}{l}\text { Average } \\
\text { no of } \\
\text { students } \\
\text { per section }\end{array}$ & $\begin{array}{l}\text { Teacher's } \\
\text { work load }\end{array}$ & \\
\hline 1 & Galama & $\sqrt{ }$ & $\mathrm{X}$ & $\mathrm{X}$ & $\mathrm{X}$ & $\mathrm{X}$ & 70 & 18 & \\
\hline 2 & Angentu & $\mathrm{X}$ & $\mathrm{X}$ & $X$ & $\sqrt{ }$ & $\mathrm{X}$ & 41 & 10 & \\
\hline 3 & Negade & $\sqrt{ }$ & $\mathrm{X}$ & $\mathrm{X}$ & $\sqrt{ }$ & $\sqrt{ }$ & 55 & 20 & \\
\hline 4 & Agarfa & $\sqrt{ }$ & $\mathrm{X}$ & $\sqrt{ }$ & $\mathrm{X}$ & $\mathrm{X}$ & 61 & 18 & \\
\hline 5 & Maliyu & $\mathrm{X}$ & $\mathrm{X}$ & $\mathrm{X}$ & $\sqrt{ }$ & $\mathrm{X}$ & 47 & 17 & \\
\hline 6 & Goro & $\sqrt{ }$ & $\mathrm{X}$ & $X$ & $\sqrt{ }$ & $X$ & 75 & 18 & \\
\hline 7 & Sofumer & $\mathrm{X}$ & $\mathrm{X}$ & $X$ & $\mathrm{X}$ & $\mathrm{X}$ & 66 & 5 & \\
\hline 8 & Ginir & * & $\mathrm{X}$ & $\sqrt{ }$ & $\sqrt{ }$ & $\sqrt{ }$ & 48 & 16 & \\
\hline 9 & Gasara & $\sqrt{ }$ & $\mathrm{X}$ & $X$ & $\sqrt{ }$ & $X$ & 55 & 21 & \\
\hline 10 & $\begin{array}{l}\text { Melka } \\
\text { Mica }\end{array}$ & $\sqrt{ }$ & $\mathrm{X}$ & $\mathrm{X}$ & $\mathrm{X}$ & $\mathrm{X}$ & 68 & 12 & \\
\hline 11 & $\begin{array}{c}\text { Dallo } \\
\text { Manna }\end{array}$ & $\sqrt{ }$ & $\mathrm{X}$ & $\mathrm{X}$ & $\mathrm{X}$ & $\mathrm{X}$ & 64 & 18 & \\
\hline 12 & Welabu & $\sqrt{ }$ & $\mathrm{X}$ & $X$ & $\sqrt{ }$ & $X$ & 60 & 20 & \\
\hline
\end{tabular}

From the table 3.3 the condition of facilities in the schools by itself can predict the level of implementation of laboratory work s in the secondary schools. Sanbitu, Maliyu Burka and Sofumer secondary schools do not even have laboratory room. Only Ginnir secondary school has separate lab room for each subject (Physics, chemistry, biology). All the schools do not have lab manual, and only two schools (Ginnir and Agarfa) have lab technicians. More than $50 \%$ of the schools possess Lab materials although not sufficient. Yet the available materials were not functional. Only Negade and Ginnir secondary schools take their students to science laboratory. Average number of students per section is also above the standard set by MOE. As per the standard set by MOE, average number of students per class is 40 .but $50 \%$ of the sample schools hold more than 60 students per section. This is also another barrier for the implementation of practical activities. A close-ended questionnaire was administered to natural science teachers to measure the level of existence of important conditions (factors) for implementation of laboratory work $\mathrm{s}$ in their school and presented in table 3.6 below. 
Table 3.4 important conditions (factors) for the implementation of practical activities specified in science curriculums.

\begin{tabular}{|c|c|c|c|c|c|c|}
\hline $\begin{array}{l}\text { Sr. } \\
\text { No. }\end{array}$ & Questionnaire for Science Teachers & $\begin{array}{l}\text { Strongly } \\
\text { disagree } \\
\text { (1) }\end{array}$ & $\begin{array}{l}\text { Disagree } \\
(2)\end{array}$ & $\begin{array}{l}\text { neither agree } \\
\text { nor } \\
\text { disagree(3) }\end{array}$ & Agree(4) & $\begin{array}{l}\text { Strongly } \\
\text { agree(5) }\end{array}$ \\
\hline 1 & $\begin{array}{l}\text { Practical activities specified in science } \\
\text { curriculum are the important part of the } \\
\text { curriculum that should be implemented }\end{array}$ & - & - & - & $\begin{array}{l}16 \\
(22 \%)\end{array}$ & $56(78 \%)$ \\
\hline 2 & $\begin{array}{l}\text { It is impossible to perform practical } \\
\text { activities in the absence of well- } \\
\text { equipped laboratory }\end{array}$ & & & & $\begin{array}{l}12 \\
(17 \%)\end{array}$ & $60(83 \%)$ \\
\hline 3 & $\begin{array}{l}\text { There are trainings organized by } \\
\text { administration bodies (Woreda, zonal, } \\
\text { regional, MOE) that enable science } \\
\text { teachers to implement the laboratory } \\
\text { work }\end{array}$ & $\begin{array}{l}72 \\
(100 \%)\end{array}$ & - & - & - & - \\
\hline 4 & $\begin{array}{l}\text { There is skilled laboratory technician in } \\
\text { my subject to assist of laboratory work }\end{array}$ & $70(97 \%$ & $2(3 \%)$ & - & - & - \\
\hline 5 & $\begin{array}{l}\text { We have well equipped science } \\
\text { laboratory in our school }\end{array}$ & $60(83 \%)$ & $\begin{array}{l}10 \\
(14 \%)\end{array}$ & & $\begin{array}{l}2 \\
(3 \%) \\
\end{array}$ & \\
\hline 6 & $\begin{array}{l}\text { Our class room condition(transparency, } \\
\text { arrangement, class size) is conducive } \\
\text { for demonstration of some practical } \\
\text { activities }\end{array}$ & $12(17 \%)$ & $\begin{array}{l}30 \\
(42 \%)\end{array}$ & & $\begin{array}{l}16 \\
(22 \%)\end{array}$ & $14(19 \%)$ \\
\hline 7 & $\begin{array}{l}\text { I include practical activities in } \\
\text { assessment of my students' } \\
\text { performance }\end{array}$ & $65(90 \%)$ & $7(10 \%)$ & & & \\
\hline 8 & $\begin{array}{l}\text { The Number of students per class is } \\
\text { manageable for practical activities }\end{array}$ & $70(97 \%)$ & $2(3 \%)$ & & & \\
\hline 9 & $\begin{array}{l}\text { We have schedule for taking the } \\
\text { students to science laboratory }\end{array}$ & $68(94 \%)$ & & & $\begin{array}{l}2 \\
(3 \%)\end{array}$ & $\begin{array}{l}2 \\
(3 \%) \\
\end{array}$ \\
\hline 10 & $\begin{array}{l}\text { There are supports from education } \\
\text { offices (Woreda, zonal, regional, } \\
\text { MOE) to facilitate for the } \\
\text { implementation of science practical } \\
\text { activities }\end{array}$ & $50(69 \%)$ & $5(7 \%)$ & $\begin{array}{l}7 \\
(10 \%)\end{array}$ & $\begin{array}{l}10 \\
(14 \%)\end{array}$ & - \\
\hline
\end{tabular}

Table 3.4 has dictated conditions which directly or indirectly affect the implementation of laboratory work in secondary schools. All the teachers believe that practical activities are the important part of the curriculum that should be implemented. But they believe the presence of well-equipped laboratory for the implementation. The responses to question No 3 and 4 indicate there are no professional supports as well as no laboratory technician to enhance practice of practical activities. The schools also do not have schedule for laboratory (question 9) and there are no practical activities in the assessment of students' performance. The responses to item No 10 also indicate least effort by education offices to facilitate the schools environment for the implementation of science practical activities. These results are in agreement with the findings from interview with principals and observation checklists for school facilities. Analysis of the results in table 3.6 indirectly reveals the level of presence of laboratory work s in the teaching learning processes of the secondary schools. Students' response to close-ended questionnaire shown below (table 3.5) also confirms these results. 
Table 3.5 The extent to which students experience practical activities specified in science curriculum

\begin{tabular}{|c|c|c|c|c|}
\hline Sr.No & Questionnaire & Always & sometimes & Never at all \\
\hline 1 & $\begin{array}{l}\text { Learning natural sciences through practical activities is } \\
\text { more interesting than theoretical classes }\end{array}$ & $240(70 \%)$ & $98(28 \%)$ & $7(2 \%)$ \\
\hline 2 & $\begin{array}{l}\text { In teaching Natural sciences our teachers use practical } \\
\text { activities specified in the text book }\end{array}$ & - & $58(17 \%)$ & $287(83 \%)$ \\
\hline 3 & $\begin{array}{l}\text { Our Natural sciences teachers make efforts in teaching us } \\
\text { through laboratory work s }\end{array}$ & $35(10 \%)$ & $110(32 \%)$ & $200(58 \%)$ \\
\hline 4 & $\begin{array}{l}\text { Due to shortage of equipment we didn't face in laboratory } \\
\text { work }\end{array}$ & $250(72 \%)$ & $40(12 \%)$ & $55(16 \%)$ \\
\hline 5 & $\begin{array}{l}\text { Our teacher give us practical assignments that we perform } \\
\text { at home or in the fields }\end{array}$ & - & $35(10 \%)$ & $310(90 \%)$ \\
\hline 6 & $\begin{array}{l}\text { Our natural sciences teachers use demonstration of } \\
\text { practical activities in the classroom while teaching }\end{array}$ & $12(3 \%)$ & $78(23 \%)$ & $255(74 \%)$ \\
\hline 7 & $\begin{array}{l}\text { Our teachers include practical activities in assessment of } \\
\text { our performance in natural sciences }\end{array}$ & $4(1 \%)$ & $21(6 \%)$ & $320(93 \%)$ \\
\hline 8 & $\begin{array}{l}\text { Our natural sciences teachers take us to science laboratory } \\
\text { for performing practical activities }\end{array}$ & $12(3 \%)$ & $43(12 \%)$ & $290(85 \%)$ \\
\hline
\end{tabular}

Students' response to question No 1 has showed their interest in learning sciences through practical activities. $78 \%$ of the students responded that they are always interested in practical activities than theoretical classes. The responses to item number 2, 3 and 6 shows that the teachers do not use laboratory work $\mathrm{s}$ in the teaching learning process. Also the responses to question number 5 and 7 also shows that practical activities are not included in the assessments of students' performance. Additional, response to question number 8 also has confirmed that $85 \%$ of the students responded their natural science teachers do not take them to laboratory to perform practical activities.

Generally, data collected from school principals, natural science teachers, students and observation checklists for school facilities show that practical activities are not being implemented in the teaching learning process, and assessment of students' performance also did not consider laboratory work. The facilities in the schools are incomplete to enable the natural science teachers to practice the practical component of the curriculum. Although a lot of work is expected to facilitate the school environment for laboratory work, least attention is given to it by concerned bodies. Capacity building training is one of the requirements by the teachers to implement the laboratory work.

\section{Summery}

The purpose of this study was to identify major factors affecting the implementation of laboratory work $\mathrm{s}$ in the teaching learning process. To achieve these objectives important Data were collected from 404 students, 72 natural science teachers, and 11 school principals using questionnaires and interview. Observation checklists were also used to assess the school facilities for the implementation of laboratory work. The collected data were analyzed using descriptive statistics (frequency, mean and percentage). Because the trained teachers described it only few teachers participated in the training, No follow ups, the training was only for a short period of time, the training was superficial and no sufficient experience to implement the laboratory work. The training was only sorting out the existing material and not how to use it.

The finding shows that there is no implementation of laboratory work except few schools. From analysis of the collected data, the following major factors were identified as barriers for the implementation of laboratory work $\mathrm{s}$ in the context of the schools. Lack of motivation from the teachers, Large class size and great work load, Lack of practical skills and professional support, Lack of lab technician (except Agarfa and Ginnir secondary schools), Lack of lab manual, Lack of Lab materials (in most schools) Data collected by observation checklists also show that there is no ground in the schools conducive for the implementation of laboratory work.

In conclusion the major challenges for the implementation of laboratory work were identified to be: large class side, Lack of school facilities (lab room, lab technician, lab material, lab manual), lack of professional support, and great work load. The educational offices should seriously plan and enforce the provision of the required facilities for the schools and professional support for the teachers.

\section{References}

1. Abrahams, I., \& Millar, R. (2008). Does laboratory work really work? A study of the effectiveness of laboratory work as a teaching and learning method in school science.

2. Endalamaw, D., Abebe, A., Meareg, G., (2017). An Investigation in to the Combined and Relative Influences of Some Selected Factors on Students' Performance in Physics Among Secondary Schools of Bale Zone, South East Ethiopia.Journal of Education and Practice.8, 19. 
3. Feyera, B. (2014).Major Factors that Affect Grade 10 Students' Academic Achievement in Science Education at Ilu Ababora General Secondary of Oromia Regional State, Ethiopia International Letters of Social and Humanistic Science. 32: 118-134

4. Hart, C., Mulhall, P., Berry, A., Loughran, J., \& Gunstone, R. (2000). What is the purpose of this experiment? Or can students learn something from doing experiments? Journal of Research in Science Teaching, 37(7), 655-675.

5. Hattingh, A. \& Rogan, J. (2007) Some factors influencing the quality of laboratory work in science classrooms. African Journal of Research in SMT Education, 11(1): 75-90.

6. Hodson, D. (1988). Experiments in science and science teaching. Educational Philosophy and Theory, 20(2), 53-66.

7. Hodson, D. (2014). Learning Science, learning about science, doing science: Different goals demand different learning methods. International Journal of Science Education, 36(15), 2534-2553.

8. Hofstein, A., \& Lunetta, V. N. (1980). The role of the laboratory in science teaching: Research implications. Paper presented at the annual meeting of the National Association for Research in science Teaching (53rd, Boston, MA, April 11-13, 1980).

9. Hofstein, A., Lunetta, V.N. (2004). "The laboratory in science education: foundation for the $21^{\text {st }}$ century". Science Education. 88:28-54

10. Högström, P., Ottander, C., \& Benckert, S. (2006). Lärares mål med laborativt arbete: Utveckla förståelse och intresse. Nordic Studies in Science Education 2(3), 54-66.http://www.planet science.com/sciteach/realscience/science_teachers_report.pdf (accessed on February 18, 2008).

11. Hult, H. (2000). Laborationen - myt och verklighet. En kunskapsöversikt över laborationer inom teknisk och naturvetenskaplig utbildning. Linköping.

12. Jacobsen, L. (2010). Linking physics labwork activities to their potential learning outcomes: does a declaration make a difference? Roskilde: Roskilde University.

13. Kolucki, B. \&Lemish, D. (2011). Communicating with Children Principles and Practices to Nurture, Inspire, Excite, Educate and Heal. UNICEF.

14. Lazarowitz, R., \& Tamir, P. (1994). Research on using laboratory instruction in science, in D. L. Gabel. (Ed.) Handbook of research on science teaching and learning (pp. 94-130). New- York: Macmillan.

15. Mji, A., \&Makgato, M. (2006). Factors associated with high school learners' poor performance: a spotlight on mathematics and physical science. South African Journal of Education, 26(2):253-266.

16. Mokotedi, R.T. (2013).Beginning Primary School Teachers' Perspectives on the Role of Subject Specialization in Botswana Colleges of Education: Implications for the Professional Development of those who did not Specialize

17. Onwu, G., Stoffel, N. (2005) Instructional functions in large, under-resourced science classes: Perspectives of South African teachers. Perspectives in Education, 23(3): 65-75.

18. Ramnarain, U. (2014). Teachers' perceptions of inquiry-based learning in urban, suburban, township and rural high schools: The context specificity of science curriculum implementation in South Africa. Teaching and Teacher Education, 38: 65-75.

19. Science Community Representing Education, SCORE. (2008). Laboratory work in science: a report and proposal for a strategic framework. London: Science Community Representing Education (SCORE). Science Review, 91 (335), 49-51. 